Annales. Etyka w Życiu Gospodarczym / Annales. Ethics in Economic Life 2018

Vol. 21, No. 1, February 2018, 57-68

doi: http://dx.doi.org/10.18778/1899-2226.21.1.05

\author{
Anna Rutkowska \\ University of Warmia and Mazury in Olsztyn \\ e-mail: anna.rutkowska@uwm.edu.pl
}

\title{
Teorie dóbr publicznych i zrównoważonego rozwoju w myśli filozoficznej Johna Locke'a
}

\section{Theories of Public Goods and Sustainable Development in the Philosophical Thought of John Locke}

Humansare not able to change their nature other than through their own actions and with the participation of others. The full development of personal life can therefore only be achieved in society. Managing the available resources, through his activity, man delineates the boundaries between the private, the individual, and the public spheres. The decisive factor in the right to private property is the individual's own work. In economic theory, public goods are a manifestation of market failure, as market mechanisms for regulating supply and demand do not apply to the market for the quantity of goods supplied to the market. The theory of public goods is therefore primarily the subject of economic research and analysis, and the idea of the common good is the domain of philosophical reflection, especially of political philosophy. Considering the dynamic progress of civilization and the associated process of exploiting the natural environment in human economic activity, the policy of proper use of natural resources, taking into account the respect for the common good of the general public, is increasingly important. The answer to the challenges of the present day is the theory of sustainable development developed, in particular, in the green economy. It is considered to be a socio-philosophical idea, the direction of economic development, as well as the direction of scientific research, and it comprehensively deals with the problem of the long-term ability of the modern economy to develop upon the criterion of intergenerational justice.

The article addresses issues of public goods theory and sustainable development in the context of Locke's philosophical thought. The emancipation of Locke's philosophical achievements manifests itself not only in the sphere of political philosophy, but also in the socio-economic context, forming the skeleton of modern democratic states. Locke's reflections, especially in the Two Treaties on Government, are an endorsement of individualism, economic freedom and economic liberalism, as well as the idea of a natural environment in the context of economic human activity. 
The practical realization of the common good in social, political and economic life suffers many difficulties in the conditions of the globalized world. Hence, interdisciplinary and deeper reflection on the real good perceived both by the individual and by the community is necessary. It also seems reasonable to discuss the ways of perceiving the common good and the public interest of present and future generations.

Keywords: public goods, sustainable development, economic liberalism, J. Locke

JEL Classification: B11, H41, P16, Q57

\section{Wprowadzenie}

Refleksja nad możliwościami ludzkiego umysłu, tkwiącym w człowieku potencjałem i zdolnością do jego aktualizowania zarówno w wymiarze indywidualnym, jak i społecznym towarzyszyła filozofom od zarania dziejów. Problematyka relacji między jednostką a społeczeństwem podejmowana była z różną intensywnością i umiejscowieniem środka ciężkości w zależności od uwarunkowań historycznych, społecznych, kulturowych, politycznych i ekonomicznych. Jednym z najwybitniejszych umysłów XVII wieku, który podejmował w swych rozważaniach problematykę wolności jednostki i funkcjonowania społeczeństwa politycznego, był John Locke (1632-1704), angielski filozof, polityk, ekonomista, lekarz i pisarz. Poglądy J. Locke’a miały znamienny wpływ na rozwój myśli filozoficznej, politycznej i społecznej w dobie oświecenia.

Intelektualny grunt angielskiego ,wieku rozumu” stanowiły podejmowane przez filozofa genetyczne i psychologiczne zagadnienia teorii poznania (empiryzm genetyczny), a także idee tolerancji, liberalizmu i konstytucjonalizmu. Punktem wyjścia dla rozważań filozoficznych J. Locke’a była jednostka, wraz z przysługującą jej szeroko rozumianą wolnością. Jego zaś wkład w rozwój ówczesnej myśli ekonomicznej przejawiał się przede wszystkim w sformułowanej przez niego teorii wartości pieniądza, będącej podstawą dla rozwoju nurtu monetaryzmu. Poglądy polityczne J. Locke’a ukształtowane zostały na gruncie empiryzmu, racjonalizmu i utylitaryzmu. Idea wolności jednostki, będąca naczelną myślą w filozofii politycznej J. Locke’a, stanowi punkt wyjścia w rozważaniach nad stanem natury, będącym okresem powszechnej szczęśliwości, aczkolwiek nacechowanym niepewnością wynikającą z możliwości dochodzenia sprawiedliwości przez jednostki w związku z naruszeniem ich praw. Wizja człowieka w filozofii J. Locke’a ukształtowana została na kanwie melioryzmu oraz optymizmu antropologicznego i historiozoficznego.

\footnotetext{
${ }^{1}$ Najważniejsze dzieła J. Locke’a w porządku chronologicznym: List o tolerancji (Letters Concerning Toleration 1689), Dwa traktaty o rzadzie (Two Treatises of Civil Government 1690), Rozważania dotyczace rozumu ludzkiego (An Essay Concerning Human Understanding 1690), Some Considerations on the Consequences of the Lowering Interest (1691), Myśli o wychowaniu (Some Thoughts Concerning Education 1693), Further Considerations Concerning Raising the Value Relating to Money (1695), The Reasonableness of Christianity, as Delivered in the Scriptures (1695).
} 
Człowiek w stanie natury nie jest zatem istotą konfliktową (jak u Thomasa Hobbesa ${ }^{2}$ ), lecz skłonną do kooperacji i zawarcia umowy społecznej ${ }^{3}$, będącej dobrowolną i racjonalną zgodą na funkcjonowanie jednostki w społeczeństwie politycznym (obywatelskim) z poszanowaniem woli ogółu.

Pionierskie i prekursorskie rozważania J. Locke’a czynią go protoplastą liberalizmu i klasykiem idei nowoczesnej państwowości. Zaproponowany przez niego podział władzy opierał się na trzech głównych filarach: władzy ustawodawczej, wykonawczej i federacyjnej. Niekwestionowany fundament intelektualny liberalizmu stanowią rozważania J. Locke'a zawarte w opublikowanym w 1690 roku dziele pt. Dwa traktaty o rzadzie. Pierwszy z nich jest polemiką z absolutyzmem, drugi natomiast stanowi zwarte kompendium zasad klasycznego liberalizmu. Celem podjętych w artykule rozważań jest przedstawienie wkładu myśli ekonomicznej J. Locke’a w rozwój teorii dóbr publicznych i zrównoważonego rozwoju.

\section{Międzygeneracyjna sprawiedliwość w dostępie do zasobów jako fundament teorii zrównoważonego rozwoju}

Wkład myśli filozoficznej J. Locke’a w rozwój idei liberalizmu ekonomicznego stanowią poglądy na temat własności prywatnej i kwestie dotyczące dziedziczenia. Rozważania dotyczące własności, zawarte zwłaszcza w Drugim traktacie o rządzie, wpisują się we współczesną teorię zrównoważonego rozwoju i teorię dóbr publicznych. Zgodnie z definicją zawartą w Światowej Strategii Ochrony Przyrody (ang. World Conservation Strategy), rozwój zrównoważony jest:

przeksztatceniem biosfery $i$ wykorzystaniem zasobów ludzkich, ekonomicznych oraz zasobów przyrody nieożywionej i ożywionej dla zaspokojenia potrzeb ludzi i poprawy jakości ich życia, który uwzględnia czynniki społeczne, ekologiczne i ekonomiczne, wielkość zasobów przyrody oraz - w przypadku możliwości wyboru jednej z opcji rozwoju - korzyści i straty wynikające z tego wyboru w bliższej i odległej przyszłoścí ${ }^{4}$.

$\mathrm{Na}$ gruncie nauk ekonomicznych teoria zrównoważonego rozwoju rozwijana jest zwłaszcza w ramach ekonomii ekologicznej i cechuje się interdyscyplinarnością podejścia badawczego. Rozpatrywana jest ona jako idea społeczno-filozoficzna, kierunek rozwoju gospodarczego, a także jako kierunek badań naukowych, co uzasadnia holistyczne ujęcie i analizę ładu przestrzennego, demograficznego, etycznego, ekonomicznego i politycznego ${ }^{5}$. Teoria ta w sposób kompleksowy traktuje o problematyce długotrwałej zdolno-

${ }^{2}$ Zob. T. Hobbes, Lewiatan, czyli materia, forma i władza państwa kościelnego i świeckiego, przeł. Cz. Znamierowski, PWN, Warszawa 1954.

${ }^{3}$ A. Szahaj, M.N. Jakubowski, Filozofia polityki, Wydawnictwo Naukowe PWN, Warszawa 2005, s. 42.

${ }^{4}$ Światowa Strategia Ochrony Przyrody. Ochrona Żywych Zasobów dla Trwałego Rozwoju, IUCN, UNEP, WWF, Liga Ochrony Przyrody, Warszawa 1985.

${ }^{5}$ D. Kiełczewski, Konsumpcja a perspektywy trwałego i zrównoważonego rozwoju, Wydawnictwo Uniwersytetu w Białymstoku, Białystok 2004, s. 1. 
ści współczesnej gospodarki do rozwoju przy spełnieniu kryterium międzygeneracyjnej sprawiedliwości. Rozwój zrównoważony polega zatem na maksymalizacji korzyści netto z rozwoju ekonomicznego, przy jednoczesnej ochronie i zapewnieniu odtwarzania użyteczności i jakości zasobów naturalnych w długim okresie ${ }^{6}$. W kontekście tych założeń rozwój gospodarczy musi obejmować niezbędne zmiany strukturalne zarówno w gospodarce, jak i w całym społeczeństwie i cechować się powinien nie tylko wzrostem dochodów per capita, ale także poprawą innych komponentów i wyznaczników dobrobytu społecznego. Rozwój zrównoważony zatem to taki, który zapewnia zaspokojenie potrzeb obecnych pokoleń, nie uniemożliwiając jednocześnie zaspokojenia potrzeb pokoleń następnych. Głównym celem zrównoważonego rozwoju jest wzrost dobrobytu w wymiarze jednostkowym i społecznym oraz kształtowanie harmonijnych relacji między człowiekiem a przyrodą. Wśród celów szczegółowych wymienić można zaspokojenie podstawowych i koniecznych dla prawidłowego rozwoju fizycznego i psychicznego człowieka potrzeb, a także osiągnięcie zrównoważonej jakości życia z poszanowaniem wartości środowiska przyrodniczego.

W świetle współczesnych założeń teorii zrównoważonego rozwoju w Dwóch traktatach o rządzie J. Locke'a dostrzec można podwaliny myślenia o środowisku przyrodniczym w kontekście gospodarczej aktywności człowieka, przejawiającej się we właściwym wykorzystaniu zasobów naturalnych i z poszanowaniem dobra ogółu społeczeństwa. Jak podkreśla bowiem J. Locke, świat dany został ludziom we władanie w celu zapewnienia jak największych korzyści z racjonalnego, czyli zgodnego z prawem rozumu, użytkowania zasobów ziemi, a zatem w celu utrzymania i pomnażania dobrobytu zarówno jednostkowego, jak i społecznego. Zgodnie z treścią fundamentalnego prawa natury (łac. ius naturale, ang. law of nature) człowiek ma być zachowany tak dalece, jak to możliwe. Istotą tego prawa jest również zachowanie społeczeństwa i każdej w nim osoby tak dalece, jak jest to zgodne z dobrem publicznym ${ }^{7}$. Fundamentalne prawo natury stanowi zasadę regulatywną dla instytucji politycznych i społecznych różnorodnych społeczeństw obywatelskich. Prawo to jest ponadto normatywne i dyrektywne. W swym zamyśle stanowi zatem nie tyle ograniczenie, co

wyznaczenie kierunku postępowania wolnej, rozumnej jednostki, zgodnie z jej właściwym interesem i nie zezwala na nic więcej niż na to, co należy do dobra ogółu tych, którzy mu podlegaja. (...) celem prawa nie jest znoszenie i ograniczanie, lecz zachowywanie i powiększanie wolności, bowiem (...) gdzie nie mam prawa, nie ma wolności ${ }^{8}$.

Fundamentalne prawo natury nie jest zasadą agregatywną, lecz dystrybutywną, co oznacza, iż nie postuluje dążenia do osiągania jak największego dobra publicznego, lecz ukierunkowuje na każdą, indywidulaną jednostkę społeczeństwa, co w kontekście teorii zrównoważonego rozwoju przejawia się w poszanowaniu prawa własności do zasobów naturalnych ziemi każdej jednostki reprezentującej zarówno pokolenie obecne, jak i przyszłe9 .

\footnotetext{
${ }^{6}$ D.W. Pearce, R.K. Turner, Economics of Natural Resources and the Environment, Harvester Wheatsheaf, London 1990.

${ }^{7}$ J. Locke, O stanie natury [w:] J. Locke, Dwa traktaty o rzadzie. Traktat drugi, tłum. Z. Rau, PWN, Warszawa $1992, \S 16$, s. $174, \S 134$, s. 257.

${ }^{8}$ Ibidem, § 57, s. 201.

${ }^{9}$ J. Rawls, Wykłady z historii filozofii polityki, tłum. S. Szymański, Wydawnictwa Akademickie i Profesjonalne, Warszawa 2010, s. 186.
} 
W ekonomicznej myśli J. Locke’a nic nie zostało stworzone, aby ulegać miało marnotrawstwu, zepsuciu czy zniszczeniu. Gromadzenie zasobów oraz nabywanie, zawłaszczanie ich poprzez pracę ma jednak pewne granice. Prawo natury, które mocą swych postanowień nadaje własność, określa również jej ograniczenia. Tę granicę stanowi używanie, bowiem człowiek może tak daleko posługiwać się zasobami pożytecznymi dla zachowania jego życia, dopóki ich nie zniszczy, może też posługiwać się nimi dzięki swej pracy i rozciągnąć swą własność. Wszystko natomiast, co znajduje się poza zasięgiem jego pracy i przekracza jego udział, należy do innych ludzi ${ }^{10}$. Takie podejście charakterystyczne jest współcześnie dla myślenia ekologicznego i wpisuje się w trend tzw. konsumenta odpowiedzialnego i etycznego, a zatem konsumenta świadomego konsekwencji swoich wyborów. Rosnąca świadomość ekologiczna konsumentów oraz potrzeba aktywnej ochrony zasobów naturalnych przejawiają się w ekologicznym modelu konsumpcji, wzmacniającym działalność przedsiębiorstw ukierunkowanych na szeroko pojętą ekologię i dobrobyt społeczny ${ }^{11}$. Ponadto nieustanne przeobrażenia rzeczywistości stwarzają potrzebę poszukiwania takich środków - przede wszystkim na gruncie polityki gospodarczej - które pozwalałyby skutecznie rozwiązywać realne problemy współczesnego świata. Idea zrównoważonego rozwoju zakłada zaspokajanie podstawowych potrzeb wszystkich ludzi oraz zachowanie, ochronę i przywracanie zdrowia i integralności ekosystemu ziemi bez zagrożenia możliwości zaspokojenia potrzeb przyszłych pokoleń i bez przekraczania długookresowych granic pojemności ekosystemu. Działania i decyzje ekonomiczne, podejmowane zarówno na szczeblu krajowym, jak i międzynarodowym, prowadzić więc powinny do wyrównywania szans, przeciwdziałania marginalizacji i dyskryminacji oraz podnoszenia jakości środowiska naturalnego, m.in. poprzez ograniczanie szkodliwego wpływu produkcji i konsumpcji na stan środowiska i ochronę zasobów przyrodniczych. Praktyczną odpowiedzią na powyższe teoretyczne założenia jest rozwój proekologicznych megatrendów w konsumpcji, takich jak: ekokonsumpcja, świadoma konsumpcja, konsumpcja współpracująca (kolaboratywna), freeganizm, prosumpcja, smart shopping, domocentryzm oraz dekonsumpcja ${ }^{12}$.

Ekokonsumpcja, określana również jako konsumpcja ekologiczna lub zrównoważona, polega na celowym dążeniu do minimalizacji niekorzystnych efektów, wynikających ze spożycia dóbr konsumpcyjnych i inwestycyjnych, poprzez racjonalizację i eksploatację zasobów oraz zmniejszenie wytwarzania odpadów poprodukcyjnych i pokonsumpcyjnych. Z ekokonsumpcji wynikają trzy trendy konsumenckie, którymi są: świadoma konsumpcja, konsumpcja współpracująca oraz freeganizm. Przejawem świadomej konsumpcji jest dokonywanie wyborów konsumenckich na podstawie wiedzy na temat ich społecznych, ekologicznych i politycznych konsekwencji. Konsumpcja wspierająca jest stosunkowo nową, alternatywną formą konsumpcji. Jej istotą jest pożyczanie, wymiana i umowy barterowe. Fundament nowego nastawienia konsumentów stanowią prostota,

${ }^{10}$ J. Locke, O wtasności [w:] J. Locke, Dwa traktaty o rzadzie. Traktat drugi, tłum. Z. Rau, PWN, Warszawa 1992, § 25-33, s. 180-185.

${ }^{11}$ D. Mirońska, Zachowania nabywców na rynku - trendy $i$ wplyw na działanie przedsiębiorstw, „International Journal of Management and Economics" 2010, Vol. 27, s. 114-132; R. Matwiejczuk, Zarzadzanie marketingowo-logistyczne. Wartość i efektywność, C.H. Beck, Warszawa 2006.

${ }^{12} \mathrm{~T}$. Zalega, Nowe trendy i makrotrendy w zachowaniach konsumenckich gospodarstw domowych $w$ XXI wie$k u$, „Konsumpcja i Rozwój” 2013, nr 2 (5), s. 4. 
identyfikowalność i przejrzystość oraz udział jednostki w otaczającym ją świecie ${ }^{13}$. Relatywnie nowym zjawiskiem jest trend dekonsumpcyjny (antykonsumeryzm), rozumiany jako świadome i celowe ograniczenie konsumpcji do rozmiarów racjonalnych, a zatem wynikających z naturalnych, fizycznych i psychicznych potrzeb konsumenta. Konsumpcja taka określana jest mianem godziwej lub odpowiedzialnej.

Podobną świadomość ekologiczną i ukierunkowanie człowieka na poszanowanie tego, co wszystkim ludziom wspólne, dostrzec można w tekstach J. Locke’a. Człowiek może bowiem zawłaszczać zasoby, respektując zasady międzygeneracyjnej sprawiedliwości, a zatem jedynie w taki sposób, który nie przynosi szkody i uszczerbku innym członkom społeczeństwa. W obliczu zidentyfikowanych trendów konsumpcyjnych i przyświecających im idei można zatem stwierdzić, że człowiek powinien dążyć do osiągania optymalnych korzyści z użytkowania zasobów i minimalizacji poziomu ich marnotrawstwa. Takie rozumne postępowanie zapewniłoby bowiem ład społeczny oraz poszanowanie własności i dobra wspólnego nie tylko w perspektywie krótkookresowej, lecz także z uwzględnieniem dobra przyszłych pokoleń, a zatem przyczyniałoby się do rozwoju zrównoważonego.

\section{Teoria dóbr publicznych, czyli o relacjach między tym, co prywatne, a tym, co wspólne}

Własność w świetle różnych koncepcji definiowana jest przez pryzmat wiązki uprawnień wraz z warunkami określającymi sposoby ich wykonywania. Pojęcie własności indywidualnej jednostki w węższym znaczeniu w myśli J. Locke’a odnoszone jest do mienia, majątku i dobytku materialnego. W szerszym zaś aspekcie własność stanowi mienie naturalne, życie oraz wolność jednostki. W Locke’owskim ujęciu własność prywatna powstała w stanie natury wraz z trzema jej naturalnymi tytułami: pracą, dziedziczeniem oraz dobroczynnością, co zaprzecza tezie, iż tylko władza daje uprawnienie do własności. Źródłem własności prywatnej u J. Locke’a jest praca, przez którą człowiek nabywa prawo do rzeczy będącej przedmiotem jego wysiłku i trudu. Praca stanowi ponadto własność człowieka, co sugeruje zasadę sprawiedliwości, zgodnie z którą własność zasobów ziemi przysługiwać powinna człowiekowi według produktu jego uczciwej pracy ${ }^{14}$. Wolność korzystania z zasobów nie jest uprawnieniem wyłącznym, co oznacza, że nie można się do niego odwołać, aby odebrać jednostce bez jej zgody produkty jej pracy lub ograniczyć wolność korzystania z zasobów obecnym i przyszłym pokoleniom. Nikt zatem nie może zostać wykluczony z korzystania lub z dostępu do niezbędnych do życia środków i zasobów naturalnych ziemi ${ }^{15}$. Jak podkreśla J. Locke, wprowadzenie do obiegu pieniądza przyczyniło się jednak do nieograniczonego przywłaszczania, którego konsekwencją była dyferencjacja własności oraz zróżnicowanie uprawnień.

\footnotetext{
${ }^{13}$ A. Rostek, T. Zalega, Konsumpcja kolaboratywna wśród młodych polskich i amerykańskich konsumentów (cz. 1), „Marketing i Rynek” 2015, nr 5, s. 12, 14.

${ }^{14}$ J. Locke, O własności..., § 27, s. 181-182.

${ }^{15}$ J. Rawls, Wyktady z historii filozofii..., s. 215.
} 
Pojęcie dobra ogólnego zawarte jest zwłaszcza w Drugim traktacie o rządzie i rozumiane jest przez J. Locke’a jako suma interesów jednostek posiadających własność. Zaproponowana definicja wyklucza zatem możliwość zaistnienia konfliktu pomiędzy interesami jednostek a dobrem ogółu, bowiem pomimo że celem poszczególnych jednostek jest interes własny, to jednak łączy je interes nadrzędny - zachowanie społeczeństwa, zabezpieczającego własność, ale i umożliwiającego rozwój. Jednakże nie sposób takiego konfliktu wykluczyć, stąd też głównym celem wspólnoty politycznej i rządu jest tworzenie prawa dla regulacji i ochrony własności oraz dla obrony wspólnoty przed agresją zewnętrzną, wszystko to zaś jedynie dla dobra publicznego ${ }^{16}$.

Rozważania J. Locke’a nad dobrem prywatnym (indywidualnym), wspólnym oraz własnością zasobów odnieść można do teorii dóbr publicznych. We wszystkich współczesnych społeczeństwach gospodarujących występują dobra i usługi, które nie są przedmiotem indywidualnej konsumpcji poszczególnych jednostek, lecz są wykorzystywane wspólnie. Zaliczyć do nich można zarówno dobra naturalne, jak i dobra będące wytworem działalności ludzkiej. Przez wzgląd na ich specyficzny charakter wynikający z konsumpcji zbiorowej określane są mianem dóbr publicznych. W teorii ekonomii dobra publiczne określa się jako przejaw niedoskonałości rynku (ang. market failure), gdyż w ich przypadku nie mają zastosowania rynkowe mechanizmy regulowania podaży i popytu, decydujące o ilości dostarczanych na rynek dóbr ${ }^{17}$. Wbrew założeniom ekonomii klasycznej, „niewidzialna ręka rynku” nie jest gwarantem zaspokojenia zapotrzebowania na niektóre dobra. $Z$ tego też względu państwo, poprzez odpowiednie regulacje, podejmuje interwencję mającą na celu wytworzenie i dostarczenie na rynek dóbr publicznych, które nie muszą jednak powstawać wyłącznie w sektorze publicznym ${ }^{18}$. Zdaniem J. Locke’a natura nadała ludziom rzeczy we wspólne posiadanie i władanie. Człowiek, jako właściciel własnej osoby i pracy, ma w sobie podstawę własności. Dobro wspólne staje się dobrem prywatnym (własnym), będącym w dyspozycji danego człowieka, w wyniku włożonej pracy i wykorzystania własnych umiejętności w czerpaniu korzyści z użytkowania wspólnych zasobów, praca daje bowiem uprawnienia do własności rzeczy ${ }^{19}$. Co więcej, bogactwo jest produktem pracy. Zawłaszczenie dobra wspólnego w celu pomnażania bogactwa jest etycznie słuszne i społecznie pożądane. J. Locke stawia pytanie o moment ustanowienia własności prywatnej, mianowicie: kiedy własność wspólna staje się własnością indywidualną i jakie warunki o tym przesądzają?

Istnienie dóbr publicznych wiąże się z występowaniem pewnych potrzeb zbiorowych i koniecznością ich zaspokojenia. Dobro publiczne (ang. public good) współcześnie w kontekście językowym oznacza dobro powszechne, nieprywatne, służące ogółowi. Zgodnie z definicją zaproponowaną przez P. Samuelsona, dobra publiczne to takie, które mogą być konsumowane przez dodatkowych konsumentów bez ponoszenia dodatkowych kosztów ${ }^{20}$.

${ }^{16}$ R.H. Popkin, A. Stroll, Filozofia, tłum. J. Karłowski, N. Leśniewski, A. Przyłębski, Wydawnictwo Zysk i S-ka, Poznań 1994, s. 115.

${ }^{17}$ A. Kargol-Wasiluk, Teoria dóbr publicznych a paradygmat ekonomii sektora publicznego, „Zarządzanie Publiczne" 2008, nr 3, s. 91-117.

${ }^{18}$ F. Foldvary, Public Goods and Private Communities: The Market Provision of Social Services, Edward Elgar, Aldershot 1994, s. 1.

19 J. Locke, O własności..., § 44-45, s. 193-195.

${ }^{20}$ P.A. Samuelson, The Pure Theory of Public Expenditure, "The Review of Economics and Statistic" 1954, Vol. 36, nr 4, s. 387. 
Dobra publiczne mają pewne wyróżniające je, specyficzne cechy. Rozróżnienie dóbr publicznych od prywatnych dokonywane jest przez ekonomistów na podstawie odpowiedzi na dwa zasadnicze pytania. Pierwsze z nich dotyczy możliwości rywalizacji, drugie zaś możliwości wykluczenia (wyłączenia) z konsumpcji. Konsumpcja o charakterze rywalizacyjnym (ang. rival consumption) oznacza, że jeżeli pewne dobro jest wykorzystywane przez jedną osobę, to nie może być wykorzystywane przez kogoś innego. Konsumpcja nierywalizacyjna (ang. non-rival consumption) występuje wówczas, gdy spożycie dobra przez jedną osobę nie zmniejsza możliwości korzystania z niego przez innych ${ }^{21}$. U J. Locke’a kryterium wykluczania z konsumpcji stanowi indywidualna praca człowieka. Niewykluczający charakter konsumpcji (ang. non-exclusive consumption) oznacza, że wykluczenie (wyłączenie) poszczególnych jednostek z konsumpcji dóbr jest niemożliwe technicznie lub organizacyjnie bądź też jest bardzo kosztowne. Niemożność wyłączenia z konsumpcji oznacza innymi słowy, że przy konsumpcji danego dobra każda dodatkowa użyteczność uzyskana przez konsumenta nie powoduje wzrostu kosztów. Każdy dodatkowy konsument korzystający z dobra publicznego nie przyczynia się zatem do wzrostu kosztów związanych z konsumpcją tegoż dobra. Kryterium klasyfikacji dóbr na prywatne i wspólne stanowi u J. Locke’a praca. Człowiek korzysta z zasobów natury w takim stopniu, w jakim zostały one umieszczone przez naturę. Jego praca dołącza zaś coś, co wyklucza już powszechne uprawnienie innych do tych zasobów. W ekonomii współczesnej określane jest to mianem wartości dodanej. Praca w ujęciu J. Locke’a stanowi bezsprzecznie własność pracownika, a zatem żaden inny człowiek, poza nim samym, nie może być uprawniony do tego, co raz zostało zawłaszczone i w sytuacji, gdy pozostają jeszcze dobra wspólne dostępne dla innych ludzi. Praca stanowi o różnicy między tym, co indywidualne, a tym, co wspólne, bowiem tworzy wartość dodaną do zasobów naturalnych ziemi. To dzięki pracy możliwe jest zdobycie osobistych uprawnień do bogactw natury. Własność zasobów w ujęciu J. Locke’a nie wymaga zatem zgody i przyzwolenia ogółu społeczeństwa na ich przywłaszczenie. Przyzwolenie członków społeczeństwa na zawłaszczenie dóbr nie jest ponadto możliwe ze względów epistemologicznych. Kradzieżą nie jest przywłaszczenie poprzez pracę tego, co należało do wszystkich ludzi jako dobro wspólne, publiczne. Gdyby istniała bowiem konieczność uzyskania zgody całego społeczeństwa na zbiór owoców, człowiek bez względu na obfitość zasobów głodowałby i umarłby z głodu ${ }^{22}$.

Do tego stwierdzenia J. Locke’a nawiązuje inny współczesny podział dóbr publicznych, będący propozycją D.L. Weimera i A.R. Vininga ${ }^{23}$. Uwzględnia on, obok cech fizycznych dóbr, także cechę związaną z popytem na nie, czyli tzw. ,zatorowość”, „obciążoność" danego dobra (ang. congestible public good). Dobro jest obciążone, jeśli marginalny społeczny koszt konsumpcji przewyższa marginalny indywidualny koszt konsumpcji. Obciążoność dobra w danym czasie zależna jest natomiast od poziomu popytu. Zmiany popytu mogą być wywołane zmianą cen relatywnych, zmianą dochodów konsumentów czy też zmianą technologii. Może wówczas nastąpić przesunięcie popytu z poziomu, któremu nie towarzyszą efekty zewnętrzne konsumpcji, do poziomu, w którym się one ujawniają. W niektórych przypadkach wzrost w popycie może zmieniać efekty zewnętrzne konsump-

\footnotetext{
${ }^{21}$ J.E. Stiglitz, Ekonomia sektora publicznego, Wydawnictwo Naukowe PWN, Warszawa 2007.

22 J. Locke, O własności..., § 25-33, s. 180-185.

${ }^{23}$ D.L. Weimer, A.R. Vining, Policy Analysis, Upper Saddle River, New Jersey: Prentice Hall 1999.
} 
cji, czyniąc dobro bardziej lub mniej obciążonym, przepustowym (np. zmiany natężenia ruchu samochodów na autostradzie w ciągu dnia). Czysto nierywalizacyjne i nieobciążone dobra wykazują zerowe marginalne koszty konsumpcji ${ }^{24}$.

Pod koniec XX wieku, w odpowiedzi na toczące się procesy globalizacyjne, pojawiła się próba opracowania koncepcji globalnych dóbr publicznych, w świetle której dobra te, oprócz posiadania typowych cech dóbr publicznych, spełniają dodatkowo dwa kryteria - ich oddziaływanie musi mieć charakter ponadnarodowy oraz ich konsumpcja przez jedną społeczność nie może ograniczać konsumpcji przez inną społeczność ${ }^{25}$. Należy przy tym podkreślić, iż do tej pory badacze zajmujący się problematyką dóbr publicznych nie wypracowali spójnego katalogu dóbr publicznych, czego przejawem są rozbieżności w klasyfikacji spotykane w literaturze przedmiotu. Według I. Kaul i R. Mendozy, autorów rozszerzonej teorii dóbr publicznych, globalnymi dobrami publicznymi są klasycznie definiowane czyste dobra publiczne, mieszane dobra publiczne, ponadto są to dobra zdeterminowane społecznie, czyli pożądane dla rozwoju społeczeństwa ${ }^{26}$. W niektórych opracowaniach podkreśla się także ich międzypokoleniowy charakter. Katalog tak zdefiniowanych globalnych dóbr publicznych obejmuje zatem: globalne dobra naturalne o powszechnym dostępie (atmosfera, morza i oceany itp.); globalne dobra stworzone przez człowieka o powszechnym (wiedza niekomercyjna), ograniczonym (wiedza opatentowana) dostępie oraz o sieciowym charakterze (wielostronne umowy handlowe, transport międzynarodowy); dobra będące wynikiem polityki globalnej (uniwersalne dobra prywatne, niewytwarzane dla konkretnego odbiorcy: edukacja, powszechna opieka zdrowotna itp. $)^{27}$. Na gruncie socjologicznym rozważa się podział na globalne dobra publiczne, do których zalicza się zasoby aksjonormatywne bądź kulturowe dobra publiczne, czyli podzielane normy i wartości społeczne ${ }^{28}$. Można zatem stwierdzić, iż współcześnie następuje niejako powrót do źródeł i swoiste przewartościowanie - wobec nieracjonalnych postaw i destrukcyjnej działalności człowieka względem zasobów naturalnych ziemi nadrzędne stają się wartości środowiska przyrodniczego, z których wywodzą się następnie wartości witalne człowieka. Zmiany dokonujące się na przestrzeni ostatnich lat odzwierciedlają przyjęcie myślenia strategicznego, cechującego się perspektywiczną troską o jakość życia na ziemi i przyszłość następnych pokoleń. Jak natomiast podkreśla J. Locke, każdy człowiek jest zobowiązany do zachowania siebie samego. Powinien także zachować resztę rodzaju ludzkiego, a zatem nie jest on uprawniony do ograniczania bądź pozbawiania życia i niezbędnych do życia środków innego człowieka. Wszyscy ludzie muszą powstrzymywać się od naruszania wolności i uprawnień przysługującym innym. Należy bowiem żyć zgodnie z prawem natury, nakazującym pokój i zachowanie całego rodzaju ludzkiego ${ }^{29}$. Ograniczanie natomiast marnotrawstwa zasobów poprzez racjonalną ich alokację jest społecznie pożądane. Podejście zaprezentowane przez J. Locke’a ma odzwierciedlenie w dążeniu

\footnotetext{
${ }^{24}$ A. Kargol-Wasiluk, Teoria dóbr publicznych..., op. cit., s. 95-96.

${ }^{25}$ S. Deneulin, N. Townsend, Public Goods, Global Public Goods and Common Goods, WeD Working Paper 18, University of Bath, Bath 2006, s. 6.

${ }^{26}$ Providing Global Public Goods: Managing Globalization, red. I. Kaul, P. Conceição, K. Le Goulven, R.U. Mendoza, Oxford University Press, New York 2003; M. Brol, Globalne dobra publiczne, „Prace Naukowe Akademii Ekonomicznej im. Oskara Langego we Wrocławiu” 2008, nr 1191, s. 36.

${ }^{27}$ Ibidem.

${ }^{28}$ P. Sztompka, Socjologia. Analiza społeczeństwa, Wydawnictwo Znak, Kraków 2002, s. 257.

${ }^{29}$ J. Locke, O stanie natury..., § 4-7, s. 165-167.
} 
współczesnych gospodarek i społeczeństw do zrównoważonego rozwoju. Obecne decyzje związane z wyborem: dobra publiczne versus dobra prywatne, dobra dostarczane przez sektor publiczny versus podaż dóbr zapewniana przez sektor prywatny muszą być bowiem podejmowane w oparciu nie tylko o ekonomiczne, ale także społeczne przesłanki. W dyskusji o relacji człowieka względem natury i środowiska przyrodniczego należałoby zatem uwzględnić bogaty dorobek myśli zarówno ekonomicznej, jak i filozoficznej.

\section{Podsumowanie}

Ekonomia jest nauką społeczną traktującą o sposobach gospodarowania jednostki i społeczeństwa w warunkach nieograniczoności ludzkich potrzeb i ograniczoności zasobów czynników produkcji, służących wytwarzaniu dóbr i usług zaspokajających te potrzeby. Życie i praktyka gospodarcza wymagają zatem nieustannego podejmowania decyzji dotyczących rozdysponowywania ograniczonych zasobów, którego celem jest zaspokojenie potrzeb określonej zbiorowości w najbardziej efektywny sposób. Ów problem szczególnie mocno uwidacznia się w kontekście sektora publicznego, dostarczającego konkretnych dóbr i świadczącego konkretne usługi publiczne na rzecz społeczeństwa. Jak zauważa J. Kleer, współcześnie sektor publiczny powinien być gwarantem stabilności państwa poprzez zapewnienie należytej realizacji podstawowych funkcji państwa w zakresie struktury administracyjno-instytucjonalnej, niezbędnej do prawidłowego funkcjonowania społeczeństwa i gospodarki, opartych na cywilizacji przemysłowej oraz kształtowaniu podstaw cywilizacji postindustrialnej ${ }^{30}$. Odpowiedzialność sektora publicznego za realizację tych zadań i zamierzeń jest tym większa, że, w przeciwieństwie do sektora prywatnego kształtowanego przez prawa rynku i zasady przede wszystkim mikroekonomiczne, sektor ten obok kryteriów i zasad czysto ekonomicznych uwzględniać musi także uwarunkowania społeczne, oceniane na poziomie makroekonomicznym i makrospołecznym.

Można by rzec, że nie sposób jest w pełni zrozumieć liberalizmu - również ekonomicznego - bez odwołania do myśli klasyków, kształtujących fundamentalne założenia i formułujących naczelne idee oraz zasady funkcjonowania jednostki w społeczeństwie. Rozważania J. Locke’a dotyczące filozofii polityki stanowiły asumpt do badań podejmowanych przez takich myślicieli czasów nowożytnych, jak D. Hume, A. Smith, J.S. Mill. Podstawą społeczeństwa politycznego nie jest prawo, lecz umowa społeczna. Pogląd ten czyni z J. Locke'a jednego z najwybitniejszych - obok T. Hobbesa i J.J. Rousseau - filozofów kontraktualizmu, stanowiącego podwaliny współczesnej demokracji. Myśl filozoficzna J. Locke’a znalazła odzwierciedlenie w Deklaracji Niepodległości Stanów Zjednoczonych i Konstytucji Stanów Zjednoczonych, zawierających ideę wolności jednostki, której rdzeń stanowi przysługujące każdemu człowiekowi naturalne prawo do życia, wolności osobistej i posiadania własności przedstawione w dziele Dwa traktaty o rzadzie. Teorie prawa natury oraz własności prywatnej niewątpliwie miały wpływ na rozwój klasyczne-

${ }^{30}$ J. Kleer, Identyfikacja rodzajów dóbr wytwarzanych przez sektor publiczny [w:] Sektor publiczny w Polsce i na świecie. Między upadkiem a rozkwitem, red. J. Kleer, CeDeWu, Warszawa 2005, s. 32. 
go liberalizmu, w którym wolność postrzegana jest jako uprawnienie moralne i normatywne, a własność prywatna stanowi zarazem gwarancję i dowód istnienia wolności politycznej ${ }^{31}$. Czyniąc wolność jednostki podstawą dobrego ustroju politycznego, J. Locke odróżnia jednocześnie naturalną wolność człowieka, czyli wolność występującą w stanie natury, od wolności człowieka w społeczeństwie, podlegającej ograniczeniom wynikającym z istnienia normy prawnej określającej zasady współżycia społecznego, co stanowić może istotny wkład w rozwój współczesnej teorii dóbr publicznych. Emanacja myśli filozoficznej J. Locke’a przejawia się współcześnie nie tylko w sferze filozofii polityki, tworząc szkielet współczesnych państw demokratycznych, lecz także w kontekście społeczno-ekonomicznym. Rozważania J. Locke'a zawarte w Dwóch traktatach o rzadzie stanowią aprobatę dla indywidualizmu, wolności gospodarczej i liberalizmu ekonomicznego. W koncepcji Locke’owskiej prawo do własności prywatnej, budowane na pojęciu samoposiadania, wynika z fundamentalnego prawa natury i stanowi przypadek połączenia praw szczególnych i powszechnych. Człowiek w swoich autonomicznych decyzjach jest jednak ograniczony prawem natury chroniącym interes zarówno indywidualny, jak i społeczny. Poszanowanie dobra zarówno indywidualnego, jak i wspólnego obecnych i przyszłych pokoleń stanowi natomiast fundament zrównoważonego rozwoju ekonomicznego. W laborystycznej koncepcji wartości J. Locke przyjmuje, że praca człowieka stanowi proporcję 9/10 wartości każdej rzeczy, co usprawiedliwia istnienie prywatnej własności. Jeśli bowiem wysiłek jednostki powoduje zmianę w świecie na lepsze, to ma ona prawo do rzeczy, którą wydobyła ze stanu natury. J. Locke zakłada więc, iż praca i wysiłek z nią związany stanowią konieczny, aczkolwiek niewystarczający warunek zawłaszczenia ${ }^{32}$. Jakie są praktyczne implikacje owych założeń w dobie współczesnych uwarunkowań gospodarczych? Należałoby przede wszystkim podkreślić konieczność maksymalizacji korzyści z rozwoju ekonomicznego przy jednoczesnej ochronie zasobów naturalnych i zapewnieniu ich odtwarzania użyteczności i jakości w dłuższej perspektywie. Człowiek w indywidualnych i wolnych działaniach, poprzez kształtowanie harmonijnych relacji między jednostką a społeczeństwem, powinien uwzględniać dobro wspólne, dbając jednocześnie o zapewnienie międzygeneracyjnej sprawiedliwości w dostępnie do szeroko pojętych zasobów.

\section{Bibliografia}

Brol M., Globalne dobra publiczne, „Prace Naukowe Akademii Ekonomicznej im. Oskara Langego we Wrocławiu" 2008, nr 1191.

Deneulin S., N. Townsend, Public Goods, Global Public Goods and Common Goods, WeD Working Paper 18, University of Bath, Bath 2006.

Foldvary F., Public Goods and Private Communities: The Market Provision of Social Services, Edward Elgar, Aldershot 1994.

Hobbes T., Lewiatan, czyli materia, forma i władza państwa kościelnego i świeckiego, przeł. Cz. Znamierowski, PWN, Warszawa 1954.

\footnotetext{
${ }^{31}$ M. Król, Historia myśli politycznej. Od Machiavellego po czasy współczesne, Arche, Gdańsk 2001, s. 41-42.

${ }^{32}$ J. Locke, Dwa traktaty o rzadzie. Traktat drugi. O własności, § 41, s. 191, § 43, s. 193.
} 
Kargol-Wasiluk A., Teoria dóbr publicznych a paradygmat ekonomii sektora publicznego, „Zarządzanie Publiczne" 2008, nr 3, s. 91-117.

Kiełczewski D., Konsumpcja a perspektywy trwałego i zrównoważonego rozwoju, Wydawnictwo Uniwersytetu w Białymstoku, Białystok 2004.

Kleer J., Identyfikacja rodzajów dóbr wytwarzanych przez sektor publiczny [w:] Sektor publiczny w Polsce i na świecie. Między upadkiem a rozkwitem, red. Kleer J., CeDeWu, Warszawa 2005.

Król M., Historia myśli politycznej. Od Machiavellego po czasy wspótczesne, Arche, Gdańsk 2001.

Locke J., Dwa traktaty o rzadzie, tłum. Z. Rau, PWN, Warszawa 1992.

Matwiejczuk R., Zarzadzanie marketingowo-logistyczne. Wartość i efektywność, C.H. Beck, Warszawa 2006.

Mirońska D., Zachowania nabywców na rynku - trendy i wplyw na działanie przedsiębiorstw, „International Journal of Management and Economics" 2010, Vol. 27, s. 114-132.

Pearce D.W., R.K. Turner, Economics of Natural Resources and the Environment, Harvester Wheatsheaf, London 1990.

Popkin R.H., A. Stroll, Filozofia, tłum. J. Karłowski, N. Leśniewski, A. Przyłębski, Wydawnictwo Zysk i S-ka, Poznań 1994.

Providing Global Public Goods: Managing Globalization, red. I. Kaul, P. Conceição, K. Le Goulven, R.U. Mendoza, Oxford University Press, New York 2003.

Rawls J., Wyktady z historii filozofii polityki, tłum. S. Szymański, Wydawnictwa Akademickie i Profesjonalne, Warszawa 2010.

Rostek A., T. Zalega, Konsumpcja kolaboratywna wśród młodych polskich i amerykańskich konsumentów (cz. 1), „Marketing i Rynek” 2015, nr 5.

Samuelson P. A., The Pure Theory of Public Expenditure, "Review of Economics and Statistic" 1954, Vol. 36, nr 4.

Stiglitz J.E., Ekonomia sektora publicznego, Wydawnictwo Naukowe PWN, Warszawa 2007.

Szahaj A., M.N. Jakubowski, Filozofia polityki, Wydawnictwo Naukowe PWN, Warszawa 2005.

Sztompka P., Socjologia. Analiza społeczeństwa, Wydawnictwo Znak, Kraków 2002.

Światowa Strategia Ochrony Przyrody. Ochrona Żywych Zasobów dla Trwałego Rozwoju, IUCN, UNEP, WWF, Liga Ochrony Przyrody, Warszawa 1985.

Weimer D.L., A.R. Vining, Policy Analysis, Upper Saddle River, New Jersey: Prentice Hall 1999.

Zalega T., Nowe trendy i makrotrendy $w$ zachowaniach konsumenckich gospodarstw domowych w XXI wieku, „Konsumpcja i Rozwój” 2013, nr 2 (5). 